\title{
A Conceptual Study of Technology Adoption of Online Mutual Fund Investment Platform
}

\author{
E. K. Dewi and R. A. Rahadi
}

\begin{abstract}
Mutual Funds is an alternative investment designed as a means to raise funds from people who have capital and have the desire to invest, but only have limited time and knowledge. In addition, Mutual Funds are also expected to increase the role of local investors to invest in the capital market. To encourage an increase in the number of investors, the first online mutual fund investment platform was launched in Indonesia in 2016. Over time, similar platforms began to appear. The theory of technology adoption is implemented in this study to analyze how technology adoption of online mutual fund investment with millennials as the main object of research. Based on various literacies, there are several factors that influence a person to adopt online mutual fund investment, namely performance expectancy, effort expectancy, social influence, facilitating conditions, hedonic motivation, price value, habits, content design quality, user interface and perceived trust.
\end{abstract}

Index Terms-Millennial generation, online mutual funds investment, technology adoption.

\section{INTRODUCTION}

Reported by Statistics Indonesia (BPS) in 2019, Indonesia was recorded to have more than 268 million population, this resulted in Indonesia occupying the fourth most populous country in the world. It is also mentioned that one third of the population in Indonesia are millennials. The Indonesia Central Securities Depository (KSEI) noted until October 2019 , there are $60 \%$ of 2.28 million people of number investors coming from the millennial generation.

Investment has an important role in the economic sector, especially in developing countries. Without adequate investment, it is difficult to expect high economic growth that results in economic prosperity for developing countries. One of the means used to accelerate the pace of development and the economy is through the capital market that is defined as an activity related to public offerings and securities trading, public companies related to securities issued, and institutions and professions related to securities.

There's a significant increase in the implementation of information technology and innovation in the financial services sector recently in Indonesia [33]. One of the real forms of innovation is the existence of online mutual funds that have begun to come widely in Indonesia. Starting in 2016, PT Manulife Asset Management Indonesia (MAMI) launched KlikMAMI, the first online mutual fund service in Indonesia which then encouraged other FinTech's to provide online mutual fund services with a variety of different features from one another [26].
The number of mutual funds investors have been improving since the existence of online mutual funds investment platforms. The reasons for mutual funds are chosen by the majority of investors, besides the easy and quick process, some online platforms also allow investors to deposit their money with a small nominal which is certainly very suitable for middle society in Indonesia. With the advancement of technology, the development of the capital market industry, and the existence of fintech, prospective investors have been easier to open securities accounts.

However, the number of mutual fund investors is still relatively small when compared to the number of millennial populations in Indonesia. Meanwhile, the government believes the growth of investor numbers can be one of the supporting factors of macroeconomic growth [27]. Transforming conventional mutual funds to an online basis is not easy since not many online mutual funds are successfully implemented by Indonesian investors [33]. As of now, there are still few studies that discuss factors influencing technology adoption towards online mutual funds in Indonesia, especially Millennials as the object of the study.

\section{LITERATURE REVIEW}

\section{A. Millennials in Investment}

Definition of millennials based on [28] are sociable, optimistic, talented, well-educated, collaborative, openminded, influential, and achievement oriented. In a survey of IDN Research Institute in their report [36] has conducted a survey in several big cities of Indonesia, it is found that only $2 \%$ of the total millennials' expenditure is used for investment, and $51 \%$ is used for shopping. This finding was also revealed in a 2017 report by [5]. In that report also found that only $39.4 \%$ of 600 respondents had already had investment planning.

\section{B. Mutual Fund}

In the study of [34] said that mutual funds are a pool of saving money from a number of investors who have a common financial goal. Then, the professional management would invest the money that had been collected from investors in capital market instruments, such as shares, securities and debentures. The return is gained from these investments and the capital appreciations realized are shared by its unit's holder in each proportion.

Mutual funds are an ideal form of investment for today's complex and modern financial scenarios. At present the number of mutual fund investments is increasing, when 
compared to other financial instruments. Investing in mutual funds is safer and also produces more portfolio investment returns. Mutual funds are said to be the best channel to accommodate small investor funds while making a significant contribution to the capital market [29].

\section{Mutual Fund in Indonesia}

Investor interest in mutual funds continues to increase. Reporting from the Financial Services Authority of Indonesia states that there is a significant increase in the number of SID (Single Investor Identification) increases in October 2019. This is directly proportional to the AUM (Asset Under Management), which is the management fund which also has increased from the month September to October 2019 [6].

\section{Framework Development}

Knowing that online mutual funds have only been launched in Indonesia since 2016 and that the number of users is growing year on year, it should be emphasized how important it is to use a research model for the implementation of technology from a number of previous studies. There is several literature in this area indicating that a variety of analytical mechanisms have been developed to investigate the implementation intentions of related information technology and information systems (IT / IS) for example the technology acceptance model (TAM) [15], the technology-organization and environment (TOE) framework [35], the theory of planned behaviour (TPB) [1], extended of the unified theory of acceptance and use of technology (UTAUT2) [39], etc. Many of these ideas have used fundamental concepts in the fields of psychology, communication and IT to explain the motives of different types of IT / IS at the human and firm level [24]. Any of these models have been applied to further research to enhance predictive capabilities.

TAM2 [37] and UTAUT2 [39] are two broad-based structures that have been used to explain the implementation goals of contemporary IT / IS. These mechanisms have been commonly used to explain acceptance preferences and distribution processes across fields varying from communications and social science to digital information systems [41]. In terms of explaining the use of IT / IS in the scope of organizations, the basic TAM was built and initially consisted of perceived ease of use (PEOU), perceived usability (PU), behavior (ATT) towards the usage of specific IT / IS, behavioral intent (BI) and real use (AU) of IT / IS [42]. Venkatesh and Davis expanded the initial concept in 2000 by removing ATT and including two additional factors.

UTAUT is also another concept that is widely used by existing practitioners to analyze the acceptance expectations of the new IT / IS. This framework elaborated eight previous versions and introduced four main constructs to analyze and forecast workplace adoption of technology in an organizational background [8]. Unified theory of acceptance and use of technology (UTAUT) was proposed by evaluating eight main models: theory of reasoned action, TAM, motivational model, theory of planned behavior (TPB), combination of TAM and TPB, model of PC utilisation, innovation diffusion theory and social cognitive theory. UTAUT (2003) was converted into UTAUT2 (2012) by introducing more variables than the original UTAUT. The variables are Hedonic Motivation (HM), Price Value (PV), and Habit $(\mathrm{H})$. Although the previous model has already carried out four variables, which are Performance Expectancy (PE), Effort Expectancy (EE), Social Influence (SI) and Facilitating Conditions (FC). Such specific variables were meant to improve the applicability of UTAUT within the sense of the user. It was also concluded that the new variables in UTAUT2 would give rise to certain substantial improvements in the variation described in the sense of behavioral purpose and the use of technology [39].

Over the years, marketing research has found anomalies in the trend of acceptance of specific IT / IS around the globe, which is incomprehensible by using a single, specific design [24]. Such variations in patterns of adoption are primarily due to factors such as government policy, business development, consumer conditions and the like [19], [7]. In this context, the present study used the basic architecture of current models and expanded them by adding web design consistency (CDQ) and user interface (UI) as two new variables to resolve the specifications and underlying characteristics of the online mutual fund.

\section{E. Performance Expectancy}

Performance Expectancy was described as the degree to which a person expects that the use of technology can aid individuals in the performance of certain actions [38]. In the case of the online mutual fund, consumers believe that by using technologies to acquire any investment would increase their efficiency in the creation of investment transactions. There are six constructions from a variety of previous versions that are equivalent with $\mathrm{PE}$, which are perceived usefulness in TAM/TAM2 and TPB, extrinsic motivation in $\mathrm{MM}$, job-fit in MPCU, relative advantage in DOI, and outcome expectations in SCT.

\section{F. Effort Expectancy}

Effort expectancy was identified as the quality of ease correlated with the use of technology or the method. In the case of online mutual funds, this variable illustrates that the system is effortless to use and how easy it is to grasp the functionality of online mutual funds. This consideration is expressed in the previous versions, which are perceived ease of use adopted by TAM / TAM2, the complexity adopted by MPCU and the ease of use adopted by IDT. The original UTAUT model has taught this factor to be regarded as an integral factor, as this aspect often affects behavioral intent [38].

\section{G. Social Influence}

Social influence interpreted as the degree to which a person respected their views on specific technologies on the part of their family, relatives or associates. This person uses the online mutual fund platform to purchase such investments under the encouragement of their relations. This element is also a crucial consideration to be evaluated, since it is a direct indicator of behavioral intent. Structured as subjective norm adopted from TRA, TAM2, TPB/DTPB and C-TAM-TPB, social factors adopted from MPCU and image adopted from IDT [38].

\section{H. Facilitating Conditions}

Facilitating conditions was determined as the degree to which a person assumes that the implementation of 
technologies enabled by suffocated resources or access to and support the ecosystem is successful. In the context of online mutual funds, the facilitation conditions apply to the degree to which customers consider the application to be assisted by a working help desk and a professional staff with a strong network. The definition is constructed from three distinct constructions; TPBI DTPB and C-TAM-TPB, facilitating conditions from MPCU and compatibility adopted from IDT. In the sense of UTAUT2 device use, supporting each user depends on demand and could have a specific degree of connectivity to the various technologies present on the market [39].

\section{Hedonic Motivation}

Described as a feeling of anticipation, pleasure or enjoyment when a person uses technology [39]. The results of [9] suggest that, if a customer uses technology for his or her own sake, it is more likely to interact with the nature of pleasure and enjoyment. This person often pays more attention to the innovation of technology, where the innovation itself leads to the influence of hedonic motivation. In the field of market use, this aspect has been shown to be significant in the measurement of acceptance and practical usage of technology. Three moderating factors are often considered to be related to hedonic motivation, i.e. age, gender and experience [9].

\section{J. Price Value}

Price value illustrates that the user places technology depending on its quality and utility, and also has a huge effect on the application of technology. In the scope of the use of mobile payments, the value of the product will be favorable because the user feels that having a certain technology at a different price would benefit them as well as the values applicable to the technology. Adding this concept can serve as an indicator of behavioral intent in the use of technology [39].

\section{K. Habit}

Habit illustrates that the person interacts towards the technology and uses it automatically. It is also related to activity, where activity through the course of time can shape various forms of habit or in a specific word; experience may represent the effects of habit. If a person wants to take steps in the context of technology and has a fixed span of time, there may be one particular pattern of carrying out such acts [39] and [23].

\section{Content Design Quality}

Content design quality involves device design, simple interface, efficient functionality and up-to-date details that will affect consumers 'first experience of applications [40]. In addition, the basic specifications for great web design would include great screen layout and architecture, simple graphics and vivid color setup [31]. Ref. [2] discuss the main characteristics of website design consistency from the point of view of the customer. Current research is focused on Aladwani and Palvia's concept of web design quality as user assessment of the functionality of the website that satisfy their expectations and represent the overall excellence of the website. Several research by [40], [3], [17] and [32] examine that content design quality has an effect on customer behavioral intention. Hence, we proposed that

\section{User Interface}

User interface is customer perceptions towards the ecommerce interface quality on the website [16]. The standard of the user interface has been proven to have a crucial impact on the performance of online retail and there has been detailed consideration of the importance of the design of the customer interface on consumer habits [11]. In a study conducted by [21] has investigated how user interface would influence TAM's key variables and user behavioral intention to use a system. They found that user interface affects behavioral intention indirectly through its direct effects on perception of ease of use and usefulness. Since there is still little literature that discusses the relationship between user interfaces and behavioral intention in online mutual fund context, researchers proposed that

\section{N. Perceived Trust}

The effectiveness of the complex relationship between the consumer and the marketer relies on the degree of reciprocal trust that exists between them. Online behavior analysis indicates the value of applying a confidence element to acceptance models, as it offers a way of interpreting consumer actions while adopting and using electronic resources [10], [18] and [25]. Trust was considered to be an important factor in determining adoption intentions for similar technologies by other researchers as well [13], [43] and [14]. Hence, it is proposed that

\section{O. Behavioral Intention}

Behavioral intention is whereby the actions of the person influences the real use of one's technologies [39]. Many results from [39], [22], and [4] showed that behavioral intent may have a substantial effect on the real application of technology. Various factors such as PE, EE, PR, SI, price, trust and the like have been measured to determine BIs towards technology adoption by many previous researchers [20], [30], and [8]. In this study, BI is taken as a dependent variable.

\section{Methodology}

The first step in this research is to recognize and describe the key question. Then, it splits down into the analysis questions and priorities that this work tries to discuss and resolve the main problem. First, conduct a literature review of paper references, articles, written authors, and so on. Preliminary evidence is then obtained by spreading questionnaires with recommendations from prior literature.

There will be 3 sections within the questionnaire. The first section is demographic questions (Name, gender, occupation, monthly income, and the online mutual funds platform that they use). The second section is to measure the behavioral intention to use an online mutual fund platform that consists of 34 questions which represents each variable that has been predetermined. The variable consists of performance expectancy, effort expectancy, social influence, facilitating conditions, hedonic motivation, price value, habits, content design quality, user interface, perceived trust, and behavioral intention. In this section, the researchers want to examine the technology adoption of online mutual fund investment platforms using 6-scale likert scale. 
When all data has been gathered, it will be reviewed using a statistical method (Multi Linear Regression) and turned into information. The final stage of this study is the result and suggestion that will be used for the online mutual fund practitioner or used for future research.

\section{RESUlT AND DiscUSSION}

After reviewing various literatures, researchers have indicated determinants or drivers that have had a positive effect on adoption decisions. Using UTAUT2 as the basis of conceptual framework, and adding 3 external variables that also determine behavioral intention to use an online mutual fund investment platform which created conceptual framework below.

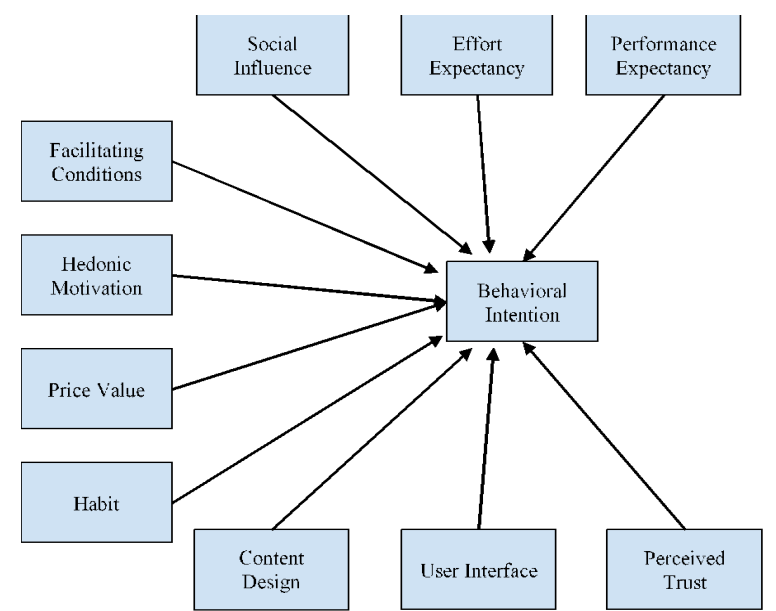

Fig. 1. Conceptual Framework for This Study from Author's Interpretation.

Researchers found that performance expectancy, effort expectancy, social influence, facilitating conditions, hedonic motivation, price value and habit will have a positive effect on behavioral intention. After analyzing several studies, it is found that perceived trust [33], content design quality [12] and user interface [21] would also be others determinants factors that affect behavioral intention. In addition, we have identified that there is limitation information available on actual adoption or usage rates for Indonesia's online mutual fund and this might be due to the limited number of studies carried in this field.

\section{CONCLUSION}

Based on the data that has been collected, it is found that performance expectancy, effort expectancy, social influence, facilitating conditions, hedonic motivation, price value and habit has direct impact on behavioral intention as well as the additional 3 variables i.e content design quality, user interface and perceived trust.

To validate the theory, researchers will check the data using a quantitative approach. Researchers will also find the relationship between each variable using multi linear regression. The outcome of this study could be used for many stakeholders such as researchers, lecturers, students, platform developers, mutual fund practitioners, and so forth.

\section{FUTURE RESEARCH}

By making this conceptual study, researchers will use this study to test and analyze technology adoption towards online mutual fund investment platforms among millennial generation in Indonesia. This study also could be used for other institutions such as government, researchers, mutual fund practitioners, and platform developers as the part of evaluating the community awareness towards online mutual funds.

\section{REFERENCES}

[1] Ajzen, I. (1991), "The theory of planned behaviour", Organizational Behaviour and Human Decision Processes, Vol.50, No.2, pp.179-211.

[2] Aladwani, A. M., \& Palvia, P. C. (2002). Developing and validating an instrument for measuring user-perceived web quality. Information \& management, 39(6), 467-476.

[3] Aladwani, A. M. (2006). An empirical test of the link between web site quality and forward enterprise integration with web consumers. Business Process Management Journal.

[4] Alalwan, A. A., Dwivedi, Y. K., Rana, N. P., \& Algharabat, R. (2018). Examining factors influencing Jordanian customers' intentions and adoption of internet banking: Extending UTAUT2 with risk. Journal of Retailing and Consumer Services, 40, 125-138.

[5] Ali, Hasanuddin \& Purwandi, Lilik. (2016). Indonesia 2020: The Urban Middle Class Millennials.

[6] Almawadi, I. (2019, October 31). Bareksa. From Bareksa: https:/www.bareksa.com/id/text/2019/10/31/jumlah-investormelesat-dana-kelolaan-reksadana-tembus-rp5523-triliun/23492/news

[7] Alshamaila, Y., Papagiannidis, S. \& Li, F. (2013), "Cloud computing adoption by smes in the North East of England: A multi-perspective framework", Journal of Enterprise Information Management, Vo. 26, No. 3, pp. 250-275.

[8] Amoroso, D. L., \& Magnier-Watanabe, R. (2012), "Building a research model for mobile wallet consumer adoption: the case of Mobile Suica in Japan", Journal of theoretical and applied electronic commerce research, Vol. 7, No.1, pp. 94-110.

[9] Brown, S. A., \& Venkatesh, V. (2005). Model of adoption of technology in households: A baseline model test and extension incorporating household life cycle. MIS quarterly, 399-426.

[10] Carter, L., \& Weerakkody, V. (2008). E-government adoption: A cultural comparison. Information systems frontiers, 10(4), 473-482.

[11] Chang, H. H., \& Chen, S. W. (2008). The impact of online store environments cues on purchase intention. Online information review.

[12] Chiu, C. C., \& Yang, H. E. (2016). The impact of website design features on behavioral intentions. International journal of scientific \& technology research, 5(9), 71-78.

[13] Chong, A. Y. L., Chan, F. T., \& Ooi, K. B. (2012). Predicting consumer decisions to adopt mobile commerce: Cross country empirical examination between China and Malaysia. Decision support systems, 53(1), 34-43.

[14] Chong, A. Y. L. (2013). A two-staged SEM-neural network approach for understanding and predicting the determinants of $\mathrm{m}$-commerce adoption. Expert Systems with Applications, 40(4), 1240-1247.

[15] Davis, F. D. (1989), "Perceived usefulness, perceived ease of use, and user acceptance of information technology”, MIS Quarterly, Vol. 13, pp. 319-339.

[16] Dhiranty, A., Suharjo, B., \& Suprayitno, G. (2017). An analysis on customer satisfaction, trust and loyalty toward online shop (a case study of tokopedia. com). Indonesian Journal Of Business And Entrepreneurship (IJBE), 3(2), 102.

[17] Flavian, C., Gurrea, R., \& Orus, C. (2009). Web design: a key factor for the website success. Journal of Systems and Information Technology.

[18] Gefen, D., \& Straub, D. (2003). Managing user trust in b2c e-services. E-Service, 2 (2), 7-24.

[19] Gong, W., \& Li, Z. G. (2008), "Mobile Youth in China: A cultural perspective and marketing implications", International Journal of Electronic Business, Vol. 6, No.3, pp. 261-81.

[20] Gu, J. C., Lee, S. C., \& Suh, Y. H. (2009). Determinants of behavioral intention to mobile banking. Expert Systems with Applications, 36(9), 11605-11616.

[21] Hasan, B., \& Ahmed, M. U. (2007). Effects of interface style on user perceptions and behavioral intention to use computer systems. Computers in Human Behavior, 23(6), 3025-3037.

[22] Khan, I. U., Hameed, Z., \& Khan, S. U. (2017). Understanding online banking adoption in a developing country: UTAUT2 with cultural 
moderators. Journal of Global Information Management (JGIM), 25(1), 43-65

[23] Limayem, M., Hirt, S. G., \& Cheung, C. M. (2007). How habit limits the predictive power of intention: The case of information systems continuance. MIS quarterly, 705-737.

[24] Madan, K., \& Yadav, R. (2016). Behavioral intention to adopt mobile wallet: a developing country perspective. Journal of Indian Business Research.

[25] Pavlou, P. A. (2003). Consumer acceptance of electronic commerce: Integrating trust and risk with the technology acceptance model. International journal of electronic commerce, 7(3), 101-134.

[26] Pramisti, N. Q., \& Chandra, Y. (2017, April 17). Ramai-ramai Jualan Reksa Dana via Fintech. Retrieved from https://tirto.id/ramai-ramaijualan-reksa-dana-via-fintech-cmRa

[27] Priyoharto, G. (2019, July 27). Investasi Tinggi Dorong Pertumbuhan Ekonomi dan Lapangan Kerja? Retrieved from https://news.detik.com/kolom/d-4641798/investasi-tinggi-dorongpertumbuhan-ekonomi-dan--lapangan-kerja

[28] Raines, C. (2002). Managing Millennials.

[29] Rathnamani, V. (2013). Investor's preferences towards mutual fund industry in Trichy. IOSR Journal of Business and Management, 6(6), 48-55.

[30] Schierz, P. G., Schilke, O., \& Wirtz, B. W. (2010). Understanding consumer acceptance of mobile payment services: An empirical analysis. Electronic commerce research and applications, 9(3), 209216.

[31] Shatnawi, R., \& Alzu'bi, A. (2011). A verification of the correspondence between design and implementation quality attributes using a hierarchical quality model. IAENG International Journal of Computer Science, 38(3), 225-233.

[32] Semuel, H., \& Wijaya, S. (2019). The Analysis Website Quality, Intention to Use The Website and Behavioral Intention Netizen Indonesia Batik-Tenun Traditional Product of Indonesia (Doctoral dissertation, Petra Christian University).

[33] Shulhan, F., \& Oetama, R. S. (2019, August). Analysis of Actua System Use from Bukareksa Mutual Fund Feature Using Technology Acceptance Model. In 2019 International Conference on Information Management and Technology (ICIMTech) (Vol. 1, pp. 186-191). IEEE.

[34] Singh, B. K. (2011). A Study on Investors' Attitude towards Mutual Funds as an Investment Option . Journal Of Asian Business Strategy, VOL. 1(2), 8-15.

[35] Tornatzky, L. and Fleischer, M. (1990), The process of technology innovation, Lexington Books, Lexington, MA.

[36] Utomo, W. P. (2019). Indonesia Millennial Report 2019. IDN Research Institute.

[37] Venkatesh, V., \& Davis, F. D. (2000). A theoretical extension of the technology acceptance model: Four longitudinal field studies. Management science, 46(2), 186-204.

[38] Venkatesh, V., Morris, M. G., Davis, G. B., \& Davis, F. D. (2003). User acceptance of information technology: Toward a unified view. MIS quarterly, 425-478

[39] Venkatesh, V., Thong, J. Y., \& Xu, X. (2012). Consumer acceptance and use of information technology: extending the unified theory of acceptance and use of technology. MIS quarterly, 157-178.

[40] Wakefield, R. L., Stocks, M. H., \& Wilder, W. M. (2004). The role of web site characteristics in initial trust formation. Journal of Computer Information Systems, 45(1), 94-103.

[41] Williams, M. D., Rana, N. P., \& Dwivedi, Y. K. (2015). The unified theory of acceptance and use of technology (UTAUT): a literature review. Journal of enterprise information management.

[42] Wu, J. H., \& Wang, S. C. (2005), "What drives mobile commerce?: An Empirical evaluation of the revised technology acceptance model", Information \& Management, Vol. 42, No.5, pp.719-729.

[43] Zhang, L., Zhu, J., \& Liu, Q. (2012), "A meta-analysis of mobile commerce adoption and the moderating effect of culture", Computers in Human Behaviour, Vol. 28, No.5, pp. 1902-1911.

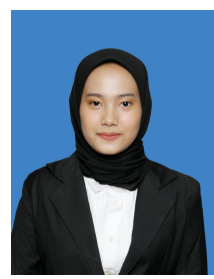

Elena Kusuma Dewi is a final year undergradu student in School of Business Management fr Institut Teknologi Bandung. Has experienced managing a small business "Pepo" as their $\mathrm{Ch}$ Financial Officer. She has done several social proje as an Organizing Committee that implement soci entrepreneurship to empower Bandung medi enterprises. Currently work as Director of Treasury Keluarga Mahasiswa Manajemen (Cam Organization).

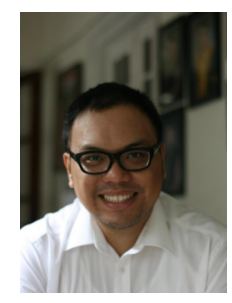

Raden Aswin Rahadi worked for 15 years in real estate, property, architecture, design, investment management, financial consulting and research industry. Holds a bachelor degree in Architecture Engineering from Institut Teknologi Bandung, hold two degrees in Management from Swiss German University, Indonesia and in Business Administration from Fachhochschule Konstanz Hochschule für Technik, Wirtschaft und Gestaltung, Germany, holds a Doctorate in Management Science from School of Business Management, Institut Teknologi Bandung. 